\title{
The Impact of Environmental Education on Environmental and Renewable Energy Technology Awareness: Empirical Evidence from Colombia
}

\author{
Hans-Erik Edsand ${ }^{1}$ (D) Tobias Broich $^{2}$
}

Received: 3 October 2018 / Accepted: 15 May 2019 / Published online: 7 June 2019

(C) The Author(s) 2019

\begin{abstract}
This paper empirically investigates to what extent environmental education (EE) at school can explain variation in environmental literacy of 15-year-olds in Colombia, while controlling for several other student- and school-level confounding factors. We use a two-level nested model, where the individual observations are nested within schools. Based on the maximum likelihood estimation method, we estimate a linear mixed model which contains both fixed effects and random effects. Our empirical results only provide weak evidence that environmental education can promote a higher level of environmental awareness. The relationship between environmental education and awareness of renewable energy technologies (RETs) is even weaker. Our findings therefore suggest that environmental education should not be considered a magic bullet in promoting environmental literacy among students. Additionally, we find more reliable predictors for environmental awareness than for awareness of RETs. Overall, the socio-economic status, stronger student science abilities, parent characteristics, and a few school-level characteristics such as quality of education resources and school ownership (public versus private) seem to be decisive factors for varying levels of environmental literacy among students in Colombia.
\end{abstract}

Keywords Environmental awareness - Environmental education · Development · Renewable energy technologies

Hans-Erik Edsand

edsandh@chalmers.se

1 Division of Environmental Systems Analysis, Chalmers University of Technology, 412 96 Gothenborg, Sweden

2 ECORYS, International Development Unit (IDU), Watermanweg 44, 3067 GG Rotterdam, Netherlands 


\section{Introduction}

Already in 1998, the Human Development Report stressed the significant pressure on the environment that was being generated by human consumption (UNDP, 1998). Since then, human consumption of natural resources has steadily increased and according to the "Planetary Boundary" framework, four out of nine Earth system processes have passed the sustainable boundaries (Steffen et al., 2015). ${ }^{1}$ Energyefficient and cleaner technologies are considered an essential aspect in reducing the human impact on the environment, while assuring a high quality of life (Dell \& Rand, 2001). Moreover, the pressing concern of climate change has placed an increased focus on renewable energy technologies (RETs) as one important mitigation strategy (IPCC, 2012). ${ }^{2}$ Moreover, previous studies conducted in developing countries have found that a lack of specific awareness of the role, along with technical and socio-economic costs and benefits of RETs, can reduce the chances for a successful implementation of "new" energy systems such as solar PV and wind energy (Kennedy \& Basu, 2013; Luthra, Kumar, Garg, \& Haleem, 2015).

Beyond the RETs' focus, augmenting a general environmental awareness is also of importance, to allow for concious human decisions concerning the challenges of sustainability. Thus, by analyzing the role of environmental education to generate both general environmental awareness about wider sustainability issues such as air pollution, biodiversity losses, material consumption relating to the boundaries of the planet, ${ }^{3}$ along with specific awareness for RETs, this paper addresses two different aspects of sustainability.

Over the past few decades, the international governmental and non-governmental organizations, policymakers, and education ministers have continually argued to enhance the environmental literacy ${ }^{4}$ of their citizens. Environmental education (EE) is considered one of the silver bullets in developing environmental knowledge, awareness, and attitudes at the student age already in order to encourage civic participation for sustainable development (Hungerford \& Volk, 1990). Whether environmental education can be considered a major determinant of improved environmental literacy is however not yet clear. The impact of several individual-related and school-related factors on environmental literacy has been covered in previous literature, mainly in developed countries (Hungerford \& Volk, 1990; Kollmuss \& Agyeman, 2002). The literature that looks at the relationship between environmental literacy and schools as well as individual characteristics in the developing world is surprisingly rare. Understanding how certain student- and school-related factors can (or cannot) influence environmental literacy, both in the developed and developing world, "can help to

\footnotetext{
${ }^{1}$ For more information concerning the Planetary Boundary framework, see Rockström et al. (2009).

${ }^{2}$ Examples of other mitigation alternatives include carbon capture and storage and carbon sinks (e.g., through reforestation) (IPCC, 2012).

${ }^{3}$ See e.g., Planetary Boundary framework for a description of sustainability challenges (Steffen et al.,2015).

${ }^{4}$ In this study, we assume that environmental literacy consists of five components: (i) environmental awareness, (ii) awareness of RETs, (iii) responsibility for sustainable development, (iv) environmental optimism, and (v) perception of environmental issues.
} 
further improve educational policies, programs, and practices for sustainable development" (Lin \& Shi, 2014, p. 74).

This study uses quantitative estimation techniques to assess several student- and school-level determinants of environmental literacy for a developing country, namely Colombia. ${ }^{5}$ By using Colombian PISA (Programme for International Student Assessment) 2006 data on environmental awareness and other environmental output measures, our study addresses the following main research questions (RQs):

- RQ 1: To what extent can environmental education (EE) in schools explain variation in environmental awareness of 15 -year-olds? ${ }^{6}$

- RQ 2: To what extent can environmental education (EE) explain variations in awareness for renewable energy technologies (RETs) of 15-year-olds?

- RQ 3: Do other individual-level characteristics, such as personal, demographic characteristics, student science abilities, or parental values and characteristics have a differential effect on varying levels of environmental literacy?

- RQ 4: To what extent does the school "infrastructure" (public versus private school, school size, teacher-student ratio, teacher shortage, proportion of qualified and/or certified teachers, quality of educational resources, etc.) promote environmental literacy?

Our findings with regard to these research questions are as follows: While we found some statistical evidence that environmental education can promote a higher level of environmental awareness (RQ 1), this is not the case for RETs awareness (RQ 2). Our results also suggest that there seem to be more reliable student-level and parent-level predictors for environmental awareness than for awareness of RETs (RQ 3). The most robust explanatory variables in understanding different levels of environmental literacy in general were the students' socio-economic status, students' enjoyment of science, hands-on activities in science lessons, and parents' science activities at age 10. Moreover, a few school-level characteristics such as quality of education resources, teacher shortage, and school ownership (public versus private) seem to be strongly correlated with varying levels of environmental awareness among students in Colombia (RQ 4). In contrast to the type of school and the quality of educational resources, teacher shortage is also significantly correlated with the other four proxies for environmental literacy. Other school-level variables such as school size or student-teacher ratio appear to have little influence on environmental literacy in Colombia.

This paper fits into the literature that explores individual- and school-related determinants of environmental literacy (Coertjens, Boeve-de Pauw, De Maeyer, \& Van Petegem, 2010; Lin \& Shi, 2014). Coertjens et al. (2010) empirically test whether schools can make a difference in promoting environmental awareness and attitudes among students using cross-sectional data of the OECD PISA 2006 for the Flemish part

\footnotetext{
${ }^{5}$ Based on the World Bank income (GNI per capita of countries classification, Colombia was in 2006 classified a low-middle income country. According to the 2015 income classification, Colombia was considered an upper-middle income (The World Bank, 2016).

${ }^{6}$ Adolescence constitutes the period when moral awareness, individual philosophies, and belief systems are being formed (Damon \& Hart, 1988) while the absorption of new knowledge (fluid intelligence) and concepts is also very high at this age (Savage, Britton, Bolton, \& Hall, 1973), making it appropriate to evaluate the influence of environmental education in 15 -year-old students.
} 
of Belgium. Lin and Shi (2014) investigate the relationship between individual- and school-related factors and environmental literacy for the USA and Canada using OECD PISA 2006 data. Compared with the two aforementioned studies, our analysis differs in four major ways. First, our study addresses a much more specific research question compared with the studies by Coertjens et al. (2010) and Lin and Shi (2014). Second, the focus of this paper is on a developing country, rather than a developed country. Third, we introduce a novel dependent variable as proxy for environmental literacy, namely the level of awareness for renewable technologies. Fourth, we include not previously used potential confounding factors at the school level as control variables.

\section{Environmental Education}

\section{The Concept of Environmental Education}

Broadly speaking, environmental knowledge includes both knowledge of and knowledge about the environment (Lucas, 1979). According to the Organisation for Economic Co-operation and Development (OECD, 2007), knowledge of can be defined as the student's ability to recall and understand a range of various environmental concepts, problems, and issues. Knowledge about can be described as the means (scientific inquiry) and goals (scientific explanations) of environmental education.

A universally accepted definition of environmental education does not exist. However, the objectives and categories set out by the United Nations Educational, Scientific and Cultural Organization (UNESCO) in the late 1970s are commonly referred to in the literature (Marcinkowski, 2003). The 1978 final report of the Tbilisi conference describes the role of environmental education as to

enable individuals of all ages and from all backgrounds, to assimilate the values, the basic concepts and the practical knowledge which will help them to an awareness of environmental problems, help them to adapt their everyday behaviour accordingly and thus make a useful contribution to the joint effort to safeguard the environment (UNESCO, 1978, p. 67).

Environmental education "resonates with the model which refers to the environment in a holistic, human-oriented approach as interacting biophysical (organisms and lifesupport systems), social (people living together), economic (livelihood, money and services) and political (power, policy and decisions) dimensions" (Goldman, Assaraf, \& Shaharabani, 2013, p. 517).

\section{Role of School Education in Generating Environmental Literacy}

Science and socioscientific topics (SSTs) in the science curriculum play an important role in preparing students to participate in modern social life effectively, shape the society in a sustainable way, and become responsible citizens in the future (Wan \& Bi, 2019). Previous empirical studies on the effects of schools and environmental education are limited and are largely restricted to developed countries. Bradley, Waliczek, and Zajicek (1999) investigate the relationship between environmental 
knowledge and environmental attitudes of US high school students in Texas. Their study suggests that students with higher knowledge scores have more favorable environmental attitudes compared with students with lower knowledge scores. In contrast, DeChano (2006) does not find a significant relationship between environmental knowledge and environmental attitude using data from high school students in Chile, England, Switzerland, and the USA.

Negev, Sagy, Garb, Salzberg, and Tal (2008) do not find a significant correlation between environmental knowledge and environmental behavior in Israel. Another contribution that uses Israel as a case study examines the impact of environmental education programs conducted by out-of-school environmental organizations: while the program increased student's sensitivity to human-environment interrelationships, its impact on the cognitive domain, in developing a more systemic understanding of environmental issues, was limited (Goldman et al., 2013).

A study by Coertjens et al. (2010) provides interesting insights into the role of schools, but is limited to a region within Belgium (Flanders). While several studentrelated factors like gender, immigrant status, and socio-economic status seem to explain differences in student's environmental attitudes and awareness, the authors also show that school policies matter: "schools in which science is taught in a more hands-on manner are associated with higher student environmental awareness whilst environmental learning activities are associated with more pro-environmental attitudes amongst students" (Coertjens et al., 2010, p. 497). A similar contribution by Lin and Shi (2014) examines individual- and school-related determinants for environmental literacy in North America (Canada and USA). The authors find that, in general, increased environmental knowledge is associated with a deeper sense of responsibility towards positive environmental impact. However, the study also provides "only" mixed results with regard to individual-level factors for both countries related to environmental awareness, attitudes, and behavior. Huang, Lin, and Yueh (2019) highlight the importance of cultivating student's creative problem solving (CPS) abilities in dealing with the environmental issues they encounter in their daily life. Using a Malaysian school as case study, Karpudewan and Roth (2018) showed that primary students who engaged in a science curriculum centered around environment-related socioscientific issues significantly improved their informal reasoning skills (e.g. using evidence-based decisionmaking, improving reasoning modes, and advancing reasoning levels).

There exist only a few studies that empirically test the relationship between environmental education and environmental literacy in emerging economies and developing countries. Examining secondary girls' perceptions regarding science learning environments and the metacognitive science learning orientation within the context of science education reform in Saudi Arabia, Kim and Hamdan Alghamdi (2019) found that science education reform efforts may gradually change Saudi science education environments and improve Saudi girls' science metacognitive learning orientation.

Using Cote d'Ivoire as a case study, Borchers, Boesch, Riedel, Guilahoux, Ouattara, and Randler (2014) found that extra-curricular environmental teaching in primary schools has a strongly positive effect on environmental knowledge and attitudes towards the environment. Haryono, Soemarno, Djati, and Setyoleksono (2014) find a significant impact of environmental education in school on students' knowledge but not on students' environmental attitudes and awareness in the Indonesian city of Probolinggo. A case study on rural Madagascar shows that children in villages who 
received environmental education had higher environmental knowledge and more positive environmental attitudes than children in the villages not exposed to the environmental education (Rakotomamonjy, Jones, Razafimanahaka, Ramamonjisoa, \& Williams, 2015).

In this paper, we aim to strengthen the overall empirical knowledge base concerning the effect of environmental education in generating environmental awareness and awareness for RETs. Moreover, we will address an existing research gap by gaining a deeper understanding of the relationship between environmental education and environmental literacy in a developing country context.

\section{Colombia's Education System}

The constitution of 1991 introduced compulsory school for children between 5 and 15 years of age. At the same time, the Colombian education system became largely decentralized giving autonomy and academic decision-making to sub-national governments as part of a wider decentralization process since the late 1970s (Faguet \& Sánchez, 2014). ${ }^{7}$ In late 1991, the Colombian government established the Program for Coverage Expansion in Secondary Education (known as PACES in Spanish), as an attempt to (i) expand private provision of public services (King, Rawlings, Gutierrez, Pardo, \& Torres, 1997), (ii) expand school capacity, and (iii) to raise secondary school enrollment rates (King, Orazem, \& Wohlgemuth, 1999).

During the 25-year-long decentralization period of the Colombian education system, a $20 \%$ rise in school enrollment occurred but the effect was unequally distributed: public school enrollment rose by $30 \%$ while private school enrollment dropped by $7 \%$ (Faguet \& Sánchez, 2008). Despite improvements in enrollment, wide discrepancies in the quality of education between different parts of the country still persist, especially between rural and urban areas (Rangel \& Lleras, 2010). Focusing on the Colombian city of Cartagena, Rangel and Lleras (2010) found that even though family socioeconomic background influenced student achievement, "school [poverty] composition and school resources explained as much as half of the effects of family background on student achievement" (p. 291).

\section{Environmental Education in Colombia}

There have been national efforts of introducing specific programs on environmental education with the aim of enabling students to become more responsible citizens (The World Bank, 2008). More precisely, since 1991, the Colombian National Constitution (Article 67) has raised education as an important tool to promote environmental awareness and protection (Sauvé, Brunelle, \& Berryman, 2005). Following Article 67, several initiatives have been taken to encourage environmental education in Colombia. One example is policy documents from the Ministry of Environment and Ministry of Education outlining objectives and financing alternatives, while also emphasizing the

\footnotetext{
${ }^{7}$ Faguet and Sánchez (2014) provide an insightful account of Colombia's decentralization process and its impact on access to social services. Colombia's decentralization process began in the late 1970s and initially only included fiscal measures aimed at strengthening municipal finances.
} 
autonomy of each region for implementation (2002). In addition, a specific committee (Interinstitutional Technical Committees of Environmental Education (CIDEA)) has been established along with specific programs School Environmental Projects (PRAE) and Citizen Projects for Environmental Education (PROCEDA) to assist the integration of environmental education in different regions and municipalities of Colombia (GEEP, 2016). Given the emphasis on autonomy and decentralization, the implementation of national educational directives is ultimately carried out by individual schools at the local level, which results in vast differences between schools concerning their emphasis on environmental education. Positive examples, such as curriculum changes to increase the focus on environmental sustainability in certain municipalities (e.g., Santa Catalina de Alejandría) or cities (e.g., Popayán), have been noted as part of the PRAE program (Ministerio de Ambiente y Desarrollon Sostenible, 2016). A full review of the implementation of environmental education initiatives across Colombia is beyond the scope of this paper. Instead, the level of environmental education across Colombia is estimated through the PISA scale (Envlearn), which is based on a five-item questionnaire about ongoing environmental learning activities (see Appendix).

\section{Data and Methodology}

We use a multilevel mixed-effects linear regression model, where the individual observations are nested within schools. Based on the maximum likelihood estimation method, we estimate a linear mixed model which contains both fixed and random effects.

\section{Sample}

We utilize the 2006 PISA dataset for Colombia which provides a rich dataset for OECD and partner countries on the 15-year-old students, parents, and schools, including a specific survey on environmental education, awareness, and attitudes (OECD, 2007, 2009). The selection of schools was made by PISA using random selection, making the sample representative for the Colombian school population (OECD, 2007). The final sample for Colombia consists of 4478 students in 165 schools.

Certain variables were available on the individual (student or parent) level, while other variables were aggregated on the school level. In order to maximize the number of observations in our analysis, we decided to keep the data on the individual level by harmonizing the school-level data with the individual level. This was achieved by assigning the school-level data to students with the corresponding school identification number. For most of the variables, we used the scales developed by PISA. A detailed description of the construction of these scales is available in the PISA 2006 technical report $(\mathrm{OECD}, 2009){ }^{8}$ Each of the PISA scales is based on different questions, including multiple items and varying response alternatives for each question. The

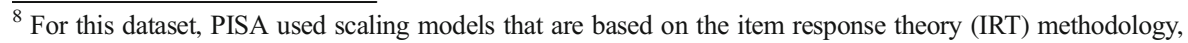
that helps determine the fit for the pooled sample. Unless otherwise noted, the items of the questionnaires were inverted for IRT scaling, so that positive WLE (weighted likelihood estimation) scores indicate a higher level of the respective scale. For example, a positive WLE score would indicate a higher enjoyment for science (one of the control variables included in this study) (OECD, 2009).
} 
questions that the scales are based on are discussed at different length in the text. Appendix provides further information about the questionnaires used to create the variables. The reliability for each scale, based on Cronbach's alpha, ${ }^{9}$ is shown in Table 1, together with summary statistics for the included variables.

Dependent Variables. In order to test our main research questions in this paper, we chose two dependent variables. As proxy for environmental awareness among 15year-old students in Colombia, we use the Envaware variable, constructed by PISA (OECD, 2009).

To address our second research question, we chose a single item from the PISA student questionnaire as proxy for RETs awareness and created the binary variable Retaware.

In order to check whether our empirical results vary depending on the measure of our main dependent variables (Envaware and Retaware), we decided to include three additional environmental output measures as dependent variables: (i) responsibility for sustainable development (Respdev); (ii) environmental optimism (Envopt); and (iii) perception of environmental issues (Envperc) (OECD, 2009). Similar to Envaware, those three variables are also scale variables created by PISA.

Main Explanatory Variable. Our main explanatory variable, environmental education (Envedu), is also a scale variable and is constructed based on a questionnaire about learning of environmental topics, denoted Envlearn by PISA (OECD, 2007, 2009). Figure 1 plots environmental awareness against environmental education. The bivariate correlation between the two variables is 0.0868 and statistically significant at the $1 \%$ level. To account for potential bias, we utilize an extensive list of carefully considered control variables at the student, parent, and school levels, motivated by previous research. ${ }^{10}$ Below, we give a justification for including these control variables in our estimation model.

Student-Level Control Variables. The control variables on the individual student level include gender, immigration status, age, and a socio-economic index that captures the economic, social, and cultural status (ESCS) of the student. Previous literature has also emphasized the role of science in shaping environmental awareness and behavior. Littledyke (2008, p. 1) argues that "science education has an important part in developing understanding of concepts that underpin environmental issues, leading potentially to pro-environmental behaviour." Thus, motivated by his and other previous findings, we also control for science ability at the student level. We include six PISA constructed scales: four forms of science teaching styles, enjoyment of science, and science activities.

Parent-Level Control Variables. Previous studies have also identified a significant relationship between the home environment and students' performance at school (OECD, 2013). Based on these findings, we also control for environmental

\footnotetext{
${ }^{9}$ Cronbach's alpha is a statistic which is used as a measure of internal consistency or reliability (see Cronbach, 1951).

${ }^{10}$ See, for example, Biel and Nilsson (2005) or de Groot and Steg (2007).
} 
Table 1 Summary statistics

\begin{tabular}{|c|c|c|c|c|c|c|}
\hline Variable & Obs. & Mean & $\begin{array}{l}\text { Std. } \\
\text { Dev. }\end{array}$ & Min & Max & $\begin{array}{l}\text { Scale } \\
\text { Reliab. }\end{array}$ \\
\hline Awareness of environmental issues (Envaware) & 3956 & -0.43 & 0.87 & -2.58 & 1.77 & 0.74 \\
\hline Awareness of renewable technologies (Retaware) & 3903 & 0.72 & 0.45 & 0.00 & 1.00 & N/A \\
\hline Responsibility for sustainable development (Respdev) & 3956 & 0.08 & 0.70 & -2.01 & 2.19 & 0.64 \\
\hline Environmental optimism (Envopt) & 3956 & 0.31 & 1.21 & -1.61 & 2.85 & 0.87 \\
\hline Perception of environmental issues (Envperc) & 3956 & 0.72 & 0.80 & -1.60 & 1.39 & 0.79 \\
\hline Environmental education & 3956 & 0.32 & 0.88 & -2.27 & 1.39 & 0.49 \\
\hline Female & 3956 & 0.55 & 0.50 & 0.00 & 1.00 & N/A \\
\hline Age & 3956 & 15.85 & 0.29 & 15.42 & 16.33 & N/A \\
\hline Native & 3855 & 0.997 & 0.06 & 0.00 & 1.00 & N/A \\
\hline Economic, social, and cultural status & 3951 & -0.94 & 1.24 & -5.03 & 2.32 & 0.73 \\
\hline Enjoyment of science & 3951 & 0.76 & 0.76 & -2.15 & 2.06 & 0.85 \\
\hline Science activities & 3947 & 0.96 & 0.77 & -1.69 & 3.38 & 0.76 \\
\hline Science teaching — application/models & 3879 & 0.56 & 0.97 & -2.46 & 2.63 & 0.71 \\
\hline Science teaching-interaction & 3904 & 0.36 & 0.81 & -2.51 & 2.47 & 0.64 \\
\hline Science teaching-student investigations & 3872 & 0.63 & 0.92 & -1.26 & 3.03 & 0.68 \\
\hline Science teaching — hands-on activities & 3885 & 0.28 & 0.90 & -2.10 & 2.91 & 0.68 \\
\hline Parents' perception of environmental issues & 3704 & 0.27 & 0.74 & -6.21 & 0.68 & 0.71 \\
\hline Parents' environmental optimism & 3694 & 0.18 & 1.15 & -1.09 & 2.93 & 0.91 \\
\hline Parents' general value of science & 3689 & 0.36 & 0.87 & -3.29 & 1.73 & 0.77 \\
\hline Parents' personal value of science & 3691 & 0.87 & 0.91 & -3.25 & 2.30 & 0.73 \\
\hline Parents' science activities at age 10 & 3695 & 0.38 & 1.08 & -2.27 & 3.33 & 0.67 \\
\hline Log school size & 3688 & 7.00 & 1.24 & 1.10 & 8.84 & N/A \\
\hline Log teacher to student ratio & 3468 & 2.95 & 1.06 & -1.02 & 3.74 & N/A \\
\hline Proportion of certified teachers & 3408 & 0.89 & 0.28 & 0.00 & 1.00 & N/A \\
\hline Teacher shortage & 3912 & 0.10 & 1.11 & -1.06 & 3.62 & 0.87 \\
\hline Proportion of teachers with ISCED 5A & 3403 & 0.75 & 1.29 & -25.19 & 1.00 & N/A \\
\hline Quality of educational resources & 3956 & -1.14 & 1.15 & -3.43 & 2.14 & 0.89 \\
\hline Responsibility for curriculum index & 3956 & -0.20 & 0.78 & -1.33 & 1.27 & N/A \\
\hline
\end{tabular}

Authors tabulations, based on PISA 2006 dataset

The values of Cronbach's alpha can be understood as high reliability $(>0.80)$, moderate reliability $(0.70-$ $0.79)$, low reliability $(0.60-0.69)$, and very low reliability $(<0.60)(\mathrm{OECD}, 2007)$. N/A, not applicable

characteristics at the parental level using five different variables: parents' perception on environmental issues, parents' environmental optimism, parents' view of the importance of science, parents' personal value of science, and parents' science activities at age 10 (see Appendix).

School-Level Control Variables. The school environment can also have a considerable effect on student performance and students' environmental literacy (Hungerford \& Volk, 1990; Kollmuss \& Agyeman, 2002). We therefore include seven control variables 
Relationship between Environmental Education and Environmental Awareness

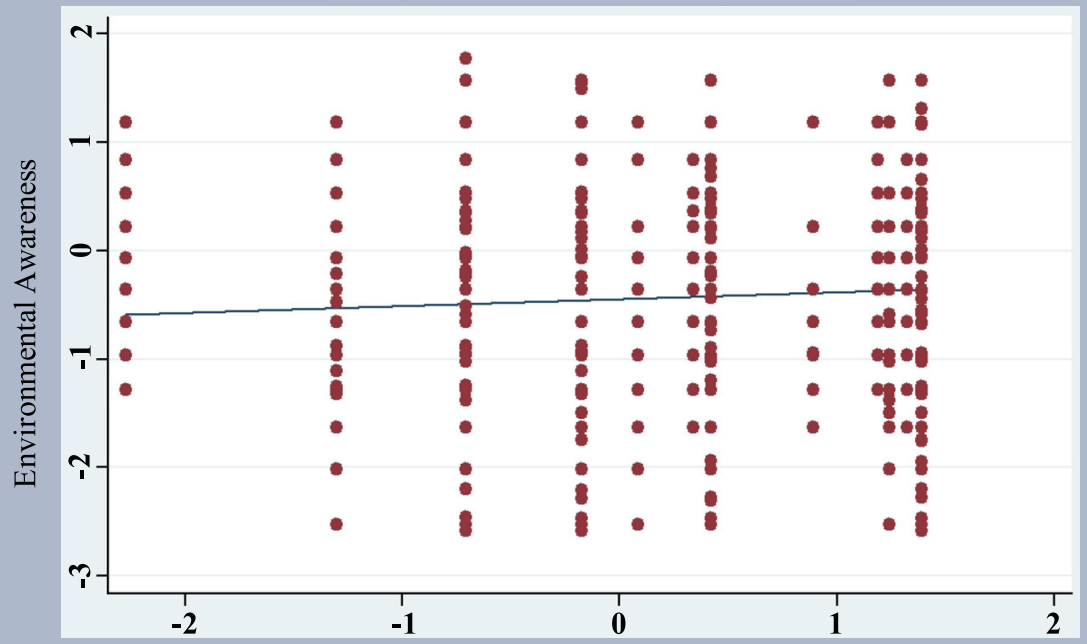

Environmental Education

Fig. 1 Relationship between environmental education and environmental awareness in Colombia. Source: authors' own calculations based on OECD (OECD, 2007, 2009)

at school level: school size, teacher to student ratio, proportion of certified teachers, proportion of teachers with ISCED 5A level qualifications, quality of educational resources, responsibility for curriculum index, and teacher shortage. ${ }^{11}$

\section{Empirical Analysis and Findings}

In our cross-sectional sample, we are interested in predicting whether environmental education has an impact on environmental output measures using student-level and school-level characteristics. In order to analyze our multilevel data, we cannot use simple OLS regression models as hierarchically structured data violate standard linear regression assumptions. We have a two-level nested model, where the individual observations are nested within schools. Based on the maximum likelihood estimation method, we estimate a linear mixed model which contains both fixed effects and random effects. The general matrix notation for our model is: $y=$ $X \beta+Z u+\mathcal{E}$ where $y$ is an $n \times 1$ vector of responses, $X$ is an $n \times p$ matrix containing the fixed effects regressors, $\beta$ is a $p \times 1$ vector of fixed-effects parameters, $Z$ is an $n \times \mathrm{q}$ matrix of random effects regressors, $u$ is a $q \times 1$ vector of random effects, and $\mathcal{E}$ is an $n \times 1$ vector of errors. More specifically, our multilevel mixed-effects linear

\footnotetext{
11 The Tcshort items were not inverted for scaling; thus, a higher WLE score reflects a higher degree of teacher shortage.
} 
regression model allows for a random slope on our main explanatory variable, environmental learning (captured by $u_{1 j}$ ):

$$
\text { envaware }_{i j}=\beta_{0}+\beta_{1} \times \text { envlearn }_{i j}+u_{0 j}+u_{1 j} \times \text { envlearn }_{i j}+\varepsilon_{i j}
$$

Before the data analysis, we identify outliers on the dependent variables by assessing whether or not they fall within a set of numerical boundaries called "inner fences" and "outer fences." Extreme outliers, i.e., points beyond an outer fence, are dropped from the analysis. We also test the normality of our dependent variables and our main explanatory variable. Values for skewness and kurtosis between -2 and +2 are considered acceptable in order to prove normal univariate distribution (George \& Mallery, 2010). ${ }^{12}$ Kurtosis and skewness values below -3 and above +3 strongly indicate non-normality. The absolute values of the skewness and kurtosis for Envedu were -0.18 and 2.08 , respectively, indicating no concern about the normality of data. Kurtosis and skewness values for our output measures are equal to 2.6 or below, indicating some concern about the normality of data. We also tested multicollinearity between the explanatory variable and the control variables (both individual-and schoollevel characteristics) with linear regression on the dependent variable. The variance inflator diagnostics were always below the threshold of 10 , suggesting that collinearity does not affect the regression coefficients.

In order to empirically test whether environmental education has a positive impact on the environmental outcome variables (Envaware and Retaware), we run a base estimation controlling for environmental education only (model 1). We then add individual demographic control variables to the model (model 2). In model 3, we control for individual science abilities. Model 4 controls for parental characteristics and model 5 controls for school-level variables. In all models, we specify the intercept to be random. Moreover, the random effects will be reported as variances rather than as standard deviations in all our models.

We would like to emphasize that based on the empirical findings presented below, it is very difficult to identify a cause-and-effect relationship. While the independent variable environmental education is generally considered the "cause" and the dependent variable environmental awareness/ awareness for RETs as the "effect" in the estimation model, the statistically significant results "only" refer to positive correlations. We do not know the direction of influence and we cannot rule out the possibility that causality could run both ways. Furthermore, confounding factors could cause a spurious association between the dependent variable(s) and the explanatory variable.

\section{Model 1}

In Table 2, we report the empirical results for our base specification. In this model, we include our main explanatory variable environmental education. Column (1) reports the results for our first main dependent variable, environmental awareness. Column (2) does the same for our second main independent variable, awareness for RETs. Since awareness for RETs is a binary variable, we run a multilevel mixed-effects ordered

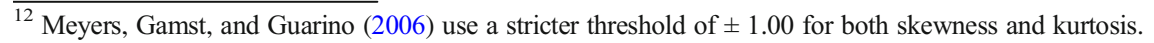


Table 2 Environmental education and environmental output measures, base model (1)
(1) Envaware
(2) Retaware
(3) Respdev
(4) Envopt
(5) Envperc

$\begin{array}{llllll}\text { Fixed effects } & & & & & \\ \text { Envlearn } & 0.07^{* * *} & 0.00 & 0.05^{* * *} & -0.08^{*} & 0.00 \\ & (0.03) & (0.05) & (0.02) & (0.04) & (0.02) \\ \text { Intercept } & -0.46^{* * *} & 0.94^{* * *} & 0.07^{* * *} & 0.34 * * * & 0.72^{* * *} \\ & (0.03) & (0.05) & (0.02) & (0.04) & (0.02) \\ \text { Random effects } & & & & & \\ \text { sd (Envlearn) } & 0.00 & 0.00 & 0.04 & 0.00 & 0.00 \\ & (0.02) & (0.14) & (0.04) & (0.00) & (0.00) \\ \text { sd (Intercept) } & 0.31 & 0.29 & 0.11 & 0.38 & 0.15 \\ & (0.02) & (0.06) & (0.02) & (0.03) & (0.02) \\ \text { sd (Residual) } & 0.81 & & 0.69 & 1.14 & 0.78 \\ & (0.01) & & (0.01) & (0.03) & (0.01) \\ \text { Model fit statistics } & & & & & \\ \text { Deviance } & 9828.78 & 4650.64 & 8366.15 & 12,493.99 & 9410.72 \\ \text { AIC } & 9833.52 & 4658.64 & 8376.15 & 12,503.99 & 9420.72 \\ \text { BIC } & 9823.52 & 4683.72 & 8407.56 & 12,535.40 & 9452.14 \\ \text { Observations } & 3956 & 3903 & 3956 & 3956 & 3956\end{array}$

Standard errors are shown in parentheses. ***Significance at the $1 \%$ level, **significance at the $5 \%$ level, *significance at the $10 \%$ level

logistic regression model for this specific dependent variable throughout the analysis. We also provide additional estimation results for three other environmental output measures (e.g., responsibility for sustainable development, environmental optimism, and perception of environmental issues) in columns (3)-(5). In each table, we also report the number of observations, the Akaike information criteria (AIC) and the Bayesian information criteria (BIC) in smaller-is-better form as well as the deviance of each model, indicating how well the model fits the data.

Looking at the relationship between environmental awareness and environmental education first, we observe a strong positive and highly statistically significant relationship. A higher level of environmental education is associated with a higher level of environmental awareness. The strong and statistically significant relationship disappears, however, when we use awareness for RETs as dependent variable. We would like to remind the reader that Retaware was a sub-component of Respdev. When we use Respdev as dependent variable, the relationship becomes positive and statistically significant again. This suggests that even though environmental education may promote responsibility for sustainable development in general, it may not necessarily encourage awareness for renewable technologies.

Last, our model also predicts that more environmental education goes hand in hand with a decrease in environmental optimism. This finding would suggest that students who learn more about the environment at school acquire a more realistic (less optimistic) picture of our global ecosystem and recent environmental developments. All in all, the results displayed in Table 2 provide only some tentative evidence that 
environmental education promotes environmental literacy as the coefficient on environmental education is statistically significant in only three out of five cases.

\section{Model 2}

In Table 3, we control for student background variables such as gender, age, immigrant status and economic, social, and cultural status (ESCS). The gender and immigrant status variables are dummy coded. With regard to the immigrant status, we distinguish between native students, first-generation students, and second-generation students. Male and native students serve as reference group for the respective variables.

Table 3 Environmental education and environmental output measures, controlling for personal characteristics at individual level (model 2)

\begin{tabular}{|c|c|c|c|c|c|}
\hline & (1) Envaware & (2) Retaware & (3) Respdev & (4) Envopt & (5) Envperc \\
\hline \multicolumn{6}{|l|}{ Fixed effects } \\
\hline Envlearn & $\begin{array}{l}0.04 \\
(0.03)\end{array}$ & $\begin{array}{c}-0.02 \\
(0.05)\end{array}$ & $\begin{array}{l}0.02 \\
(0.01)\end{array}$ & $\begin{array}{l}-0.04 \\
(0.04)\end{array}$ & $\begin{array}{l}-0.00 \\
(0.02)\end{array}$ \\
\hline Female & $\begin{array}{l}0.00 \\
(0.03)\end{array}$ & $\begin{array}{l}-0.20^{* * *} \\
(0.08)\end{array}$ & $\begin{array}{l}-0.05^{* *} \\
(0.02)\end{array}$ & $\begin{array}{l}-0.03 \\
(0.04)\end{array}$ & $\begin{array}{l}0.20^{* * * *} \\
(0.03)\end{array}$ \\
\hline Age & $\begin{array}{l}0.13^{* * * *} \\
(0.05)\end{array}$ & $\begin{array}{l}-0.13 \\
(0.13)\end{array}$ & $\begin{array}{l}-0.00 \\
(0.04)\end{array}$ & $\begin{array}{l}-0.06 \\
(0.07)\end{array}$ & $\begin{array}{l}0.07 \\
(0.04)\end{array}$ \\
\hline Generation1 & $\begin{array}{l}0.50 \\
(0.58)\end{array}$ & $\begin{array}{l}12.45 \\
(505.73)\end{array}$ & $\begin{array}{l}-0.39 \\
(0.49)\end{array}$ & $\begin{array}{l}0.30 \\
(0.82)\end{array}$ & $\begin{array}{l}0.34 \\
(0.55)\end{array}$ \\
\hline Generation2 & $\begin{array}{l}-0.45^{*} \\
(0.25)\end{array}$ & $\begin{array}{l}-0.82 \\
(0.64)\end{array}$ & $\begin{array}{l}-0.17 \\
(0.21)\end{array}$ & $\begin{array}{l}0.51 \\
(0.35)\end{array}$ & $\begin{array}{l}-0.46^{*} \\
(0.24)\end{array}$ \\
\hline ESCS & $\begin{array}{l}0.13^{* * * *} \\
(0.01)\end{array}$ & $\begin{array}{l}0.10^{* * * *} \\
(0.03)\end{array}$ & $\begin{array}{l}0.06^{* * * *} \\
(0.01)\end{array}$ & $\begin{array}{l}-0.10^{* * *} \\
(0.02)\end{array}$ & $\begin{array}{l}-0.00 \\
(0.01)\end{array}$ \\
\hline Intercept & $\begin{array}{l}-2.36^{* * *} \\
(0.73)\end{array}$ & $\begin{array}{l}3.21 \text { *** } \\
(2.03)\end{array}$ & $\begin{array}{l}0.19 \\
(0.62)\end{array}$ & $\begin{array}{l}1.19 \\
(1.04)\end{array}$ & $\begin{array}{l}-0.50 \\
(0.70)\end{array}$ \\
\hline \multicolumn{6}{|l|}{ Random effects } \\
\hline sd (Envlearn) & $\begin{array}{l}0.00 \\
(0.00)\end{array}$ & $\begin{array}{l}0.00 \\
(0.12)\end{array}$ & $\begin{array}{l}0.01 \\
(0.01)\end{array}$ & $\begin{array}{l}0.00 \\
(0.00)\end{array}$ & $\begin{array}{l}0.00 \\
(0.00)\end{array}$ \\
\hline sd (Intercept) & $\begin{array}{l}0.25 \\
(0.02)\end{array}$ & $\begin{array}{l}0.23 \\
(0.07)\end{array}$ & $\begin{array}{l}0.08 \\
(0.02)\end{array}$ & $\begin{array}{l}0.34 \\
(0.03)\end{array}$ & $\begin{array}{l}0.13 \\
(0.02)\end{array}$ \\
\hline sd (Residual) & $\begin{array}{l}0.80 \\
(0.01)\end{array}$ & & $\begin{array}{l}0.68 \\
(0.01)\end{array}$ & $\begin{array}{l}1.14 \\
(0.01)\end{array}$ & $\begin{array}{l}0.77 \\
(0.01)\end{array}$ \\
\hline \multicolumn{6}{|c|}{ Model fit statistics } \\
\hline Deviance & 9441.90 & 4478.38 & 8049.06 & $12,138.62$ & 9040.66 \\
\hline AIC & 9461.90 & 4496.38 & 8069.06 & $12,158.62$ & 9060.66 \\
\hline BIC & 9524.46 & 4552.57 & 8131.63 & $12,221.18$ & 9123.23 \\
\hline Observations & 3852 & 3805 & 3852 & 3852 & 3852 \\
\hline
\end{tabular}

Standard errors are shown in parentheses. ***Significance at the $1 \%$ level, $* *$ significance at the $5 \%$ level, *significance at the $10 \%$ level 
Compared with the results in Table 2, the positive relationship between environmental education on environmental awareness has been reduced in magnitude and is no longer statistically significant when controlling for demographic factors at the student-level. Similar to the results presented in Table 2, we do not find empirical evidence for a strong relationship between environmental education and awareness of RETs. In this model, we also start addressing our third research question, namely to what extent individual-level characteristics determine environmental literacy.

Age is positively correlated with environmental awareness. However, we do not want to overemphasize the positive coefficient on age as the analysis only includes 15- and 16-year-old students. What is however very interesting is the fact that native Colombian students (e.g., students who have at least one parent born in Colombia), tend to be more aware of environmental issues than secondgeneration immigrant students. Probably not very surprisingly, a higher socioeconomic status coincides with a higher level of environmental awareness. The same is true when we use awareness for RETs as dependent variable. Once again, the coefficient on ESCS is positive and highly statistically significant. While we did not find a significant relationship between gender and environmental awareness, we do so for awareness of RETs. The negative coefficient on female suggests that Colombian female students are less aware of RETs if compared with Colombian male students.

Overall, the results displayed in Table 3 show that when controlling for individuallevel demographic characteristics, environmental education is not statistically significant anymore regardless of the environmental output measure used. The only variable that has sufficient explanatory power in all five specifications is the socio-economic status of the student. The higher the socio-economic status of a Colombian student the more concerned he/she is with environmental issues, ceteris paribus. The findings are consistent with the US study by Lin and Shi (2014). This result can be interpreted as empirical support for the sociological theory of post-materialism (Inglehart, 1977, 1990, 1997), whereby environmental awareness is strongly influenced by economic development at the country level and a higher socio-economic status at the individual level (Brechin, 1999; Franzen, 2003).

\section{Model 3}

Since "most environmental topics (e.g. photosynthesis, biodiversity etc.) and issues (e.g. biodiversity loss, habitat fragmentation etc.) have underlying scientific principles drawing from different science fields (e.g. chemistry or mathematics)" (Coertjens et al., 2010, p. 498), we also need to control for students' science abilities (i.e., knowledge and skills). While previous studies aggregated science teaching methods scores (Scintact, Schands, Scinvest, and Scapply) for each school based on the indexes of science teaching methods at student level (Coertjens et al., 2010; Lin \& Shi, 2014), we do not aggregate the science ability indexes for each school but use those indices at the student level to test whether differences in the science ability of individuals have sufficient explanatory power (Table 4). 
Table 4 Environmental education and environmental output measures, controlling for science characteristics at individual level (model 3)

(1) Envaware

(2) Retaware

(3) Respdev

(4) Envopt

(5) Envperc

Fixed effects

Envlearn

JoyScie

ScApply

ScIntact

ScInvest

ScHands

Intercept

Random effects

sd (Envlearn)

$\begin{array}{ll} & \\ & (0.00) \\ & 0.30\end{array}$

0.30

(0.02)

sd (Residual)

0.78

(0.01)

Model fit statistics

$\begin{array}{ll}\text { Deviance } & 9281.62 \\ \text { AIC } & 9301.62 \\ \text { BIC } & 9364.21 \\ & 3863\end{array}$

Observations 3863

0.07
$(0.05)$

$0.15 * * *$

(0.05)

0.07

(0.05)

$-0.00$

(0.05)

$-0.01$

$(0.05)$

0.06

(0.01)

$0.77 * * *$

(0.06)

0.00

(0.23)

0.28

(0.06)

(1)

Standard errors are shown in *significance at the $10 \%$ level

When controlling for students' science abilities, environmental education is once again positively associated with environmental awareness, but also with responsibility for sustainable development in general. Environmental education, however, does not have a significant influence on awareness for RETs. Like in model 1, environmental education is negatively correlated with environmental optimism.

In four out of five cases, the coefficient on enjoyment of science is highly statistically significant and positive. Colombian students that tend to show a greater enjoyment of learning science are found to be more environmentally literate, holding all other factors constant. Our empirical findings are therefore in line with previous 
results by Littledyke (2008) who found a positive relationship between enjoyment of science and environmental attitudes.

All science ability variables are important in explaining student's environmental awareness. With regard to awareness for RETs, we only find enjoyment of science to be a (positive) statistically significant predictor. Awareness for RETs among Colombian students does not vary much based on the other student science abilities such as student interaction or student investigations. Another major observation is that several science abilities seem to be negatively correlated with environmental optimism.

Table 5 Environmental education and environmental output measures, controlling for parents' characteristics at individual level (model 4)

\begin{tabular}{|c|c|c|c|c|c|}
\hline & (1) Envaware & (2) Retaware & (3) Respdev & (4) Envopt & (5) Envperc \\
\hline \multicolumn{6}{|l|}{ Fixed effects } \\
\hline \multirow[t]{2}{*}{ Envlearn } & $0.06^{*}$ & 0.00 & $0.04 * *$ & -0.03 & -0.02 \\
\hline & $(0.03)$ & $(0.05)$ & $(0.02)$ & $(0.03)$ & $(0.02)$ \\
\hline \multirow[t]{2}{*}{ PqEnperc } & $0.07^{* * *}$ & -0.00 & $0.04 * *$ & -0.01 & $0.28^{* * *}$ \\
\hline & $(0.02)$ & $(0.05)$ & $(0.02)$ & $(0.03)$ & $(0.02)$ \\
\hline \multirow[t]{2}{*}{ PqEnvopt } & $-0.05 * * *$ & -0.01 & $-0.03 * * *$ & $0.38^{* * * *}$ & $-0.02 * *$ \\
\hline & $(0.01)$ & $(0.03)$ & $(0.01)$ & $(0.02)$ & $(0.01)$ \\
\hline \multirow[t]{2}{*}{ PqScimp } & -0.00 & $-0.09^{*}$ & 0.02 & 0.01 & -0.00 \\
\hline & $(0.02)$ & $(0.05)$ & $(0.01)$ & $(0.02)$ & $(0.02)$ \\
\hline \multirow[t]{2}{*}{ PqPersci } & $0.05^{* * *}$ & $0.17^{* * *}$ & $0.08 * * *$ & $0.07 * * *$ & -0.01 \\
\hline & $(0.02)$ & $(0.05)$ & $(0.01)$ & $(0.02)$ & $(0.02)$ \\
\hline \multirow[t]{2}{*}{ PqSciact } & $0.14 * * *$ & $0.15^{* * *}$ & $0.05 * * *$ & $-0.03 *$ & -0.00 \\
\hline & $(0.01)$ & $(0.04)$ & $(0.01)$ & $(0.02)$ & $(0.01)$ \\
\hline \multirow[t]{2}{*}{ Intercept } & $-0.55 * * *$ & $0.77 * * *$ & -0.02 & $0.20^{* * * *}$ & $0.68 * * *$ \\
\hline & $(0.03)$ & $(0.06)$ & $(0.02)$ & $(0.04)$ & $(0.02)$ \\
\hline \multicolumn{6}{|l|}{ Random effects } \\
\hline \multirow[t]{2}{*}{ sd (Envlearn) } & 0.00 & 0.00 & 0.06 & 0.00 & 0.00 \\
\hline & $(0.00)$ & $(0.00)$ & $(0.03)$ & $(0.00)$ & $(0.00)$ \\
\hline \multirow[t]{2}{*}{ sd (Intercept) } & 0.29 & 0.29 & 0.08 & 0.27 & 0.11 \\
\hline & $(0.02)$ & $(0.06)$ & $(0.03)$ & $(0.03)$ & $(0.02)$ \\
\hline \multirow[t]{2}{*}{ sd (Residual) } & 0.79 & & 0.68 & 1.08 & 0.76 \\
\hline & $(0.01)$ & & $(0.01)$ & $(0.01)$ & $(0.01)$ \\
\hline \multicolumn{6}{|c|}{ Model fit statistics } \\
\hline Deviance & 8818.52 & 4231.93 & 7569.15 & $10,985.34$ & 8328.47 \\
\hline AIC & 8838.52 & 4249.93 & 7589.15 & $11,005.34$ & 8348.47 \\
\hline BIC & 8900.49 & 4305.59 & 7651.12 & $11,067.30$ & 8410.43 \\
\hline Observations & 3628 & 3583 & 3628 & 3628 & 3628 \\
\hline
\end{tabular}

Standard errors are shown in parentheses. ***Significance at the $1 \%$ level, **significance at the $5 \%$ level, *significance at the $10 \%$ level 


\section{Model 4}

Since families play a fundamental role in shaping students' attitudes, views, and opinions about environmental issues, we also control for parent characteristics. The results are reported in Table 5. When examining environmental awareness, environmental education remains statistically significant.

Similar to the student science ability variables in model 3, the majority of the parental variables have significant explanatory power. Parents' perception of environmental issues, parents' personal value of science, and the level of science activities of parents at age 10 are positively correlated with students' environmental awareness. Parents' environmental optimism, however, is inversely related with students' environmental awareness and two other environmental output measures (responsibility for sustainable development and perception of environmental issues). Looking at awareness for RETs, we only find parents' science activities at age 10 and parents' personal value of science to be positive and statistically significant predictors. Surprisingly, the parents' view of the importance of science is negatively correlated with awareness for RETs, a result which should be subject for further investigation. The coefficient on environmental education remains statistically insignificant.

When examining students' varying levels of environmental optimism and perception of environmental issues, we observe that the strongest predictors for the respective outcome variables are parents' environmental optimism and parents' perception of environmental issues, respectively. These effects are much greater than the relationship between parental characteristics and students' environmental awareness and awareness for RETs.

Our results confirm the notion that students often share their parents' views towards the environment. Parents that show a stronger environmental literacy and a stronger sense of responsibility towards environmental issues tend to create an environment in which a child or student may feel more susceptible towards environmental issues. Our findings further suggest that this relationship is much more pronounced with regard to feelings of optimism or general perceptions than with regard to actual awareness or a sense of personal responsibility.

\section{Model 5}

In the previous models, we have explored the relationship between environmental literacy and environmental education controlling for student-level characteristics. In model 5 (Table 6), we will address our fourth research question by accounting for school-level characteristics. We investigate to what extent the school "infrastructure" can promote environmental awareness and awareness for RETs. The link between environmental education and awareness for RETs remains statistically insignificant even after controlling for school-level characteristics. The results in column (2) show that most school-level determinants of RETs awareness are not statistically significant.

When controlling for school-level characteristics, environmental education is no positively correlated with environmental awareness. The negative and statistically significant coefficient on public schools suggests that, holding all other factors 
Table 6 Environmental education and environmental output measures, controlling for school characteristics at school level (model 5)

\begin{tabular}{|c|c|c|c|c|c|}
\hline & (1) & (2) & (3) & (4) & (5) \\
\hline & Envaware & Retaware & Respdev & Envopt & Envperc \\
\hline \multicolumn{6}{|l|}{ Fixed effects } \\
\hline Env. Education & $\begin{array}{l}0.02 \\
(0.03)\end{array}$ & $\begin{array}{l}-0.01 \\
(0.05)\end{array}$ & $\begin{array}{l}0.03 \\
(0.02)\end{array}$ & $\begin{array}{l}-0.02 \\
(0.04)\end{array}$ & $\begin{array}{l}-0.01 \\
(0.02)\end{array}$ \\
\hline Public & $\begin{array}{l}-0.23 * * \\
(0.11)\end{array}$ & $\begin{array}{l}-0.20 \\
(0.17)\end{array}$ & $\begin{array}{l}-0.08 \\
(0.05)\end{array}$ & $\begin{array}{l}0.15 \\
(0.14)\end{array}$ & $\begin{array}{l}0.02 \\
(0.07)\end{array}$ \\
\hline Log school size & $\begin{array}{l}0.05 \\
(0.05)\end{array}$ & $\begin{array}{l}-0.06 \\
(0.08)\end{array}$ & $\begin{array}{l}-0.02 \\
(0.02)\end{array}$ & $\begin{array}{l}0.09 \\
(0.06)\end{array}$ & $\begin{array}{l}-0.04 \\
(0.03)\end{array}$ \\
\hline Log student-teacher ratio & $\begin{array}{c}-0.06 \\
(0.06)\end{array}$ & $\begin{array}{l}0.02 \\
(0.02)\end{array}$ & $\begin{array}{l}-0.01 \\
(0.03)\end{array}$ & $\begin{array}{l}-0.03 \\
(0.07)\end{array}$ & $\begin{array}{l}0.01 \\
(0.04)\end{array}$ \\
\hline Teacher shortage & $\begin{array}{l}0.05 * \\
(0.03)\end{array}$ & $\begin{array}{l}0.09^{*} \\
(0.04)\end{array}$ & $\begin{array}{l}0.02 * \\
(0.01)\end{array}$ & $\begin{array}{l}-0.07 * * \\
(0.04)\end{array}$ & $\begin{array}{l}0.04 * * \\
(0.02)\end{array}$ \\
\hline Certified teachers & $\begin{array}{l}0.17 \\
(0.11)\end{array}$ & $\begin{array}{l}0.06 \\
(0.17)\end{array}$ & $\begin{array}{l}0.05 \\
(0.06)\end{array}$ & $\begin{array}{l}-0.19 \\
(0.14)\end{array}$ & $\begin{array}{l}0.20 * * * \\
(0.07)\end{array}$ \\
\hline Quality of education resources & $\begin{array}{l}0.06^{*} \\
(0.04)\end{array}$ & $\begin{array}{l}0.07 \\
(0.05)\end{array}$ & $\begin{array}{l}0.04 * * \\
(0.02)\end{array}$ & $\begin{array}{l}-0.09^{* *} \\
(0.05)\end{array}$ & $\begin{array}{l}0.01 \\
(0.02)\end{array}$ \\
\hline Curriculum & $\begin{array}{l}0.02 \\
(0.04)\end{array}$ & $\begin{array}{l}0.11 * \\
(0.06)\end{array}$ & $\begin{array}{l}0.04 * \\
(0.02)\end{array}$ & $\begin{array}{l}-0.01 \\
(0.05)\end{array}$ & $\begin{array}{l}0.02 \\
(0.03)\end{array}$ \\
\hline Intercept & $\begin{array}{l}-0.49 * * \\
(0.21)\end{array}$ & $\begin{array}{l}1.52^{* * * *} \\
(0.36)\end{array}$ & $\begin{array}{l}0.29 * * * \\
(0.11)\end{array}$ & $\begin{array}{l}-0.24 \\
(0.28)\end{array}$ & $\begin{array}{l}0.78 * * * \\
(0.14)\end{array}$ \\
\hline \multicolumn{6}{|l|}{ Random effects } \\
\hline sd (Envlearn) & $\begin{array}{l}0.00 \\
(0.00)\end{array}$ & $\begin{array}{l}0.00 \\
(0.00)\end{array}$ & $\begin{array}{l}0.00 \\
(0.00)\end{array}$ & $\begin{array}{l}0.00 \\
(0.00)\end{array}$ & $\begin{array}{l}0.00 \\
(0.00)\end{array}$ \\
\hline sd (Intercept) & $\begin{array}{l}0.27 \\
(0.02)\end{array}$ & $\begin{array}{l}0.19 \\
(0.09)\end{array}$ & $\begin{array}{l}0.07 \\
(0.02)\end{array}$ & $\begin{array}{l}0.33 \\
(0.03)\end{array}$ & $\begin{array}{l}0.12 \\
(0.02)\end{array}$ \\
\hline sd (Residual) & $\begin{array}{l}0.82 \\
(0.01)\end{array}$ & & $\begin{array}{l}0.69 \\
(0.01)\end{array}$ & $\begin{array}{l}1.14 \\
(0.01)\end{array}$ & $\begin{array}{l}0.79 \\
(0.01)\end{array}$ \\
\hline \multicolumn{6}{|l|}{ Model fit statistics } \\
\hline Deviance & 7553.95 & 3568.82 & 6427.38 & 9574.49 & 7240.74 \\
\hline $\mathrm{AIC}$ & 7577.95 & 3590.82 & 6451.38 & 9598.49 & 7264.74 \\
\hline $\mathrm{BIC}$ & 7650.20 & 3656.90 & 6523.63 & 9670.74 & 7336.99 \\
\hline Observations & 3043 & 3003 & 3043 & 3043 & 3043 \\
\hline
\end{tabular}

Standard errors are shown in parentheses. $* * *$ Significance at the $1 \%$ level, $* *$ significance at the $5 \%$ level, *significance at the $10 \%$ level

constant, students in Colombian public schools have a lower level of environmental awareness if compared with students in Colombian private schools. At the same time, the quality of educational resources goes hand in hand with a higher level of environmental awareness. As teacher shortage is measured on a negative scale, the negative 
coefficient on teacher shortage suggests a negative influence on environmental awareness, ceteris paribus: the higher the level of teacher shortage, the lower the level of students' environmental awareness. Our first tentative explanation for this result is that school classes that suffer from teacher shortage do not have adequate human resources to provide high-quality instruction in all fields of education, including science and environment.

\section{Discussion and Concluding Remarks}

As discussed in the introduction, environmental, and specific awareness for RETs can reduce barriers to reaching sustainability goals, such as a transition towards clean energy and reducing human consumption. This paper has analyzed what effect environmental education can have on generating environmental awareness and specific RETs awareness in 15-year-olds in a developing country like Colombia. In particular, our study aimed at answering four research questions (RQ 1-RQ 4) identified in the "Introduction" of this paper.

We found some statistical evidence that environmental education can promote a higher level of environmental awareness (RQ 1), but this is not the case for RETs awareness (RQ 2). The empirical analysis above indicates that the determinants of environmental awareness and awareness for RETs vary significantly. The empirical results presented in this paper suggest that environmental education should not be considered a silver bullet in promoting environmental literacy among young people. This does not mean that schools should reduce their efforts in emphasizing and promoting environmental education at school. Schools can to some extent promote more pro-environmental attitudes in their students in both developed countries (Coertjens et al., 2010; Lin \& Shi, 2014) and developing countries (this paper). We do, however, conclude that strengthening environmental education in school curricula is a necessary but not sufficient condition for improving environmental awareness among the youth. Since children spend much time with their parents in a particular socio-economic environment, parents play a crucial role in their child's awareness for environmental issues.

With regard to RQ 3, our results also suggest that several parent and individual student characteristics seem to be decisive factors for varying levels of environmental awareness among students in Colombia, but not necessarily for awareness of RETs. The most robust explanatory variables in understanding different levels of environmental literacy in general were the students' socio-economic status, students' enjoyment of science, hands-on activities in science lessons, and parents' science activities at age 10. Several other parental and students' science ability characteristics appeared to have an impact on specific environmental output measures. In contrast, other individual student-level factors such as gender or immigration status are not strongly associated with environmental literacy in Colombia.

Regarding RQ 4, we found that certain school "infrastructure" characteristics, in particular teacher shortage, the quality of educational resources, and whether the type of school (public or private), are significantly correlated with the level of environmental 
awareness among students in Colombia. In contrast to the type of school and the quality of educational resources, teacher shortage is also significantly correlated with the other four proxies for environmental literacy. Other school-level variables such as school size or student-teacher ratio appear to have little influence on environmental literacy in Colombia. All in all, we do not find systematic empirical evidence that school-level characteristics "trump" student-level characteristics in explaining students' environmental awareness, attitudes, optimism, or perception. Environmental awareness, beliefs, and attitudes do not develop/exist in isolation. Environmental literacy is shaped through the family environment, the socio-economic status, environmental education, the school "infrastructure," and several other factors. Our study supports the theoretical viewpoint by Kollmuss and Agyeman (2002) that both internal and external factors encourage enhanced environmental literacy.

While the study provides a number of insights, there are limitations. First, even though PISA data offers a wide range of student information, PISA assesses only a limited amount of what is actually taught in schools and collects very little data on the role and contribution of teachers (see also Mortimore, 2009). Second, our study uses cross-sectional data which prevents us from analyzing the impact of environmental education on environmental output measures over time. Third, our multilevel analysis does not allow for causal inferences. Even in those cases where environmental awareness and environmental education are positively correlated, we do not know the direction of influence and we cannot rule out the possibility that causality could run both ways. Fourth, our model did not account for potential regional differences across Colombian schools. As discussed above, environmental literacy could vary significantly depending on (i) whether the school is located in a rural or urban area and (ii) whether the students live in an urban or rural context.

Our empirical results call for further research. Future research studies should investigate to what extent the impact of environmental education on environmental awareness and RETs varies between different developing countries. Another interesting research question is to what extent environmental education can induce a change in behavior and attitudes towards environmental issues over the long run. Moreover, research that investigates to what extent environmental education aimed at children can influence environmental literacy of parents is still at its infancy (see Damerell, Howe, \& Milner-Gulland, 2013). Lastly, in line with Coertjens et al. (2010), more international comparative research is vital to test our and previous results in other educational, cultural, social, and economic settings.

Acknowledgments The authors would like to thank Michiko Iizuka and Fred Gault for their valuable comments and insights during the writing of this paper. The authors are also thankful to Professor Dr. Pierre Mohnen (UNU-MERIT) for his contributions to this paper.

Funding information This research did not receive any specific grant from funding agencies in the public, commercial, or not-for-profit sectors.

\section{Compliance with Ethical Standards}

Conflict of Interest The authors declare that they have no conflict of interest. 


\section{Appendix. Variable description-PISA data and scales (for further details, see: OECD, 2009)}

Environmental awareness (Envaware): Students awareness concerning (i) greenhouse gases, (ii) genetically modified organisms (GMO), (iii) acid rains, (iv) nuclear waste, and (v) consequences of clearing forests for other land use. Four-point Likert scale answer categories: "I have never heard of this" (1 point) to "I am familiar with this and I would be able to explain this well" (4 points).

Awareness of renewable technologies (Retaware): Student agreement with statement that "Electricity should be produced from renewable sources as much as possible, even if this increases the cost." Categories: "strongly disagree" (1 point); disagree ( 2 points); agree ( 3 points), and "strongly agree" (4 points). We created the binary variable Retaware which is equal to one if the student either "strongly agreed" or "agreed" to that the question ( 0 otherwise).

Responsibility for sustainable development (Respdev): Seven items concerning sustainable development, e.g., protection of endangered species, car emissions, or waste management.

Environmental optimism (Envopt): Variable consists of six items concerning student's optimism about aspects such as air pollution, energy shortages, or nuclear waste.

Perception of environmental issues (Envperc): Variable consists of six items concerning student's perception about aspects such as air pollution, energy shortages, or nuclear waste.

Environmental education (Envedu): Principals "yes" or "no" on environmental activities: (i) outdoor education, (ii) trips to museums, (iii) trips to science and/or technology centers, (iv) extracurricular environmental projects (including research), and (v) lectures and/or seminars (e.g., guest speakers).

Gender: Gender of the student. Dummy variable. Male $=0$; female $=1$. Immigration status: Distinguishes between native students (at least one parent born in Colombia), first-generation students (born outside Colombia), and second-generation students (born in Colombia but whose parent(s) were born in another country). Age: Variable is calculated as the difference between year and month of the testing and the year and month of a student's birth.

Economic, social, and cultural status (ESCS): Index capturing economic, social, and cultural status (ESCS) of students. ESCS index is comprised of five OECD-standardized indices: highest occupational status of parents, highest educational level of parents, family wealth, cultural possessions, and home educational resources.

Science application (Scapply); Science interaction (Scintact); Student investigation (Scinvest); Hands-on-activities (Schands): Variable capturing student's reports on the frequency of using "application/model"; "science interaction"; "student investigation"; and "hands-on-activities" as a form of teaching. Students were given the response alternatives "In all lessons," "In most lessons," "In some lessons," and "Never or hardly ever"

Enjoyment of science (Joyscie): Variable based on students being asked whether they "strongly agree," "agree," "disagree," and "strongly disagree" with five different statements of their enjoyment in "reading about," "doing problems," or "acquiring new knowledge" in science.

Science activity scale (Scieact): Six items with information about the frequency with which students, "watch TV programmes," "borrow or buy books," or "visit websites" with focus on science.

Parents' environmental optimism (Pqenvopt): Consists of six items concerning parent's optimism about aspects such as air pollution, energy shortages, or nuclear waste.

Parents' perception on environmental issues (Pqenperc): Consists of six items concerning parent's perception about aspects such as air pollution, energy shortages, or nuclear waste.

Parents' view of the importance of science (Pqscimp): View about the general influence of science on society, covering aspects such as the economy or social benefits.

Parents' personal value of science (Pqpersci): How science affects them in their daily life.

Parents' science activities at age 10 (Pqsciact): How often ("very often," "regularly," "sometimes," or "never") they read books, watched TV programs, or visited website related to science at the age of 10 . 
School size (Schlsize): Derived from summing school principals' responses to the number of girls and boys at a school. Values on this index indicate total enrolment at school.

Teacher student ratio (Stratio): Size of schools divided by the number of teachers at the same school and by weighting part-time teachers by 0.5 as compared with 1.0 for full-time teachers.

Proportion of certified teachers (Propcert): Variable calculated by dividing the total number of certified teachers with the total number of teachers at the school in question.

Proportion of teachers with ISCED 5A level qualifications (Propqual): Divides the total number of ISCED $5 \mathrm{~A}$ qualified teachers with the total number of teachers at the school in question. Having acquired an ISCED 5A level education corresponds to a post-graduate or tertiary degree. In Colombia, achieving an ISCED 5A level education was calculated by PISA to equal 15.5 years of schooling.

Quality of educational resources (Scmatedu): Based on answers by school principals on seven items on whether school instruction is hindered by material shortage or school infrastructure inadequacies

Responsibility for curriculum index (Respcurr): Based on responsibilities at schools for "establishing student assessment policies," "choosing which textbooks are used," "Determining course content," and "deciding which courses are offered." The final index is a calculated ratio between "yes" answers from principals or teachers at schools compared to "yes" answers from central education actors where the higher values signify higher school autonomy in decision making in the item categories.

Teacher shortage (Tcshort): Based on four items concerning lack of science, math, language teachers and other subject, to assess the school's capacity to operate. The items were not inverted for scaling, thus, a higher WLE score reflects a higher degree of teacher shortage.

Open Access This article is distributed under the terms of the Creative Commons Attribution 4.0 International License (http://creativecommons.org/licenses/by/4.0/), which permits unrestricted use, distribution, and reproduction in any medium, provided you give appropriate credit to the original author(s) and the source, provide a link to the Creative Commons license, and indicate if changes were made.

\section{References}

Biel, A., \& Nilsson, A. (2005). Religious values and environmental concern: Harmony and detachment. Social Science Quarterly, 86(1), 178-191.

Borchers, C., Boesch, C., Riedel, J., Guilahoux, H., Ouattara, D., \& Randler, C. (2014). Environmental education in Côte D'Ivoire/West Africa: Extra-curricular primary school teaching shows positive impact on environmental knowledge and attitudes. International Journal of Science Education, 4(3), 240-259.

Bradley, J. C., Waliczek, T. M., \& Zajicek, J. M. (1999). Relationship between environmental knowledge and environmental attitude of high school students. The Journal of Environmental Education, 30(3), 17-21.

Brechin, S. R. (1999). Objective problems, subjective values, and global environmentalism: Evaluating the postmaterialist argument and challenging a new explanation. Social Science Quarterly. https://doi. org/10.1017/CBO9781107415324.004.

Coertjens, L., Boeve-de Pauw, J., De Maeyer, S., \& Van Petegem, P. (2010). Do schools make a difference in their students' environmental attitudes and awareness? Evidence from Pisa 2006. International Journal of Science and Mathematics Education, 8(3), 497-522. https://doi.org/10.1007/s10763-010-9200-0.

Cronbach, L. J. (1951). Coefficient alpha and the internal structure of tests. Psychometrika, 16(3), $297-334$. https://doi.org/10.1007/BF02310555.

Damerell, P., Howe, C., \& Milner-Gulland, E. J. (2013). Child-orientated environmental education influences adult knowledge and household behaviour. Environmental Research Letters, 8, 1-7. https://doi. org/10.1088/1748-9326/8/1/015016.

Damon, W., \& Hart, D. (1988). Self-understanding in childhood and adolescence. New York, NY: Cambridge University Press.

de Groot, J. I. M., \& Steg, L. (2007). Value orientations and environmental beliefs in five countries: How to measure egoistic, altruistic, and biospheric value orientations. Journal of Cross-Cultural Psychology, 38(3), 318-332. 
DeChano, L. M. (2006). A multi-country examination of the relationship between environmental knowledge and attitudes. International Research in Geographical and Environmental Education, 15(1), 15-28. https://doi.org/10.2167/irgee/184.0.

Dell, R. M., \& Rand, D. A. J. (2001). Energy storage - a key technology for global energy sustainability. Journal of Power Sources, 100(1-2), 2-17.

Faguet, J.-P., \& Sánchez, F. (2008). Decentralization's effects on educational outcomes in Bolivia and Colombia. World Development, 36(7), 1294-1316.

Faguet, J.-P., \& Sánchez, F. (2014). Decentralization and access to social services in Colombia. Public Choice, 160, 227-249. https://doi.org/10.1007/s11127-013-0077-7.

Franzen, A. (2003). Environmental attitudes in international comparison: An analysis of the ISSP Surveys 1993 and 2000. Social Science Quarterly, 84(2), 297-308.

GEEP. (2016). Global environmental education partnership: Colombia - policy and practice. Retrieved fromhttps://thegeep.org/learn/countries/colombia. Accessed 5 Apr 2019.

George, D., \& Mallery, M. (2010). Using SPSS for Windows step by step: A simple guide and reference. Boston, MA: Allyn \& Bacon.

Goldman, D., Assaraf, O. B. Z., \& Shaharabani, D. (2013). Influence of a non-formal environmental education programme on junior high-school students' environmental literacy. International Journal of Science Education, 35(3), 515-545.

Haryono, A., Soemarno, Djati, M. S., \& Setyoleksono, A. (2014). Learning attitude and awareness against students in cultured environmental success in Probolinggo. Journal of Environment and Earth Science, 4(16), 72-81.

Huang, T. C., Lin, W., \& Yueh, H. P. (2019). How to Cultivate an Environmentally Responsible Maker? A CPS Approach to a Comprehensive Maker Education Model. International Journal of Science and Mathematics Education, 1-16.https://doi.org/10.1007/s10763-019-09959-2

Hungerford, H. R., \& Volk, T. L. (1990). Changing learner behavior through environmental education. The Journal of Environmental Education, 21(3), 8-21.

Inglehart, R. (1977). The silent revolution: Changing values and political styles among Western publics. Princeton, NJ: Princeton University Press.

Inglehart, R. (1990). Culture shift in advanced industrial society. Princeton, NJ: Princeton University Press.

Inglehart, R. (1997). Modernization and postmodernization: Cultural, economic and political change in 43 societies. Princeton, NJ: Princeton University Press.

IPCC. (2012). In C. B. Field, V. Barros, T. C. Stocker, Q. Dahe, D. J. Dokken, K. L. Ebi, et al. (Eds.), Managing the risks of extreme events and disasters to advance climate change adaptation. Cambridge: Cambridge University Press.

Karpudewan, M., \& Roth, W. M. (2018). Changes in primary students' informal reasoning during an environment-related curriculum on socio-scientific issues. International Journal of Science and Mathematics Education, 16(3), 401-419.

Kennedy, M., \& Basu, B. (2013). Overcoming barriers to low carbon technology transfer and deployment: An exploration of the impact of projects in developing and emerging economies. Renewable and Sustainable Energy Reviews, 26, 685-693.

Kim, S. Y., \& Hamdan Alghamdi, A. K. (2019). Female secondary students' and their teachers' perceptions of science learning environments within the context of science education reform in Saudi Arabia. International Journal of Science and Mathematics Education. https://oi.org/10.1007/s10763-01809946-z.

King, E. M., Orazem, P. F., \& Wohlgemuth, D. (1999). Central mandates and local incentives: The Colombia education voucher program. World Bank Economic Review, 13(3), 467-491.

King, E. M., Rawlings, L., Gutierrez, M., Pardo, C., \& Torres, C. (1997). Colombia's targeted education voucher program: Features, coverage, and participation (No. 3). Washington, DC: Impact Evaluation of Education Reforms.

Kollmuss, A., \& Agyeman, J. (2002). Mind the gap: Why do people act environmentally and what are the barriers to pro-environmental behavior? Environmental Education Research, 8(3), 37-41. https://doi. org/10.1080/1350462022014540.

Lin, E., \& Shi, Q. (2014). Exploring individual and school-related factors and environmental literacy: Comparing U.S. and Canada using PISA 2006. International Journal of Science and Mathematics Education, 12(1), 73-97. https://doi.org/10.1007/s10763-012-9396-2.

Littledyke, M. (2008). Science education for environmental awareness: Approaches to integrating cognitive and affective domains. Environmental Education Research, 14(1), 1-17. https://doi.org/10.1080 $/ 13504620701843301$ 
Lucas, A. M. (1979). Environment and environmental education: Conceptual issues and curriculum implications. Melbourne, Australia: Australian International Press \& Pub.

Luthra, S., Kumar, S., Garg, D., \& Haleem, A. (2015). Barriers to renewable/sustainable energy technologies adoption: Indian perspective. Renewable and Sustainable Energy Reviews, 41, 762-776. https://doi. org/10.1016/j.rser.2014.08.077.

Marcinkowski, T. (2003). Commentary on Rickinson's "Learners and Learning in Environmental Education: A critical review of the evidence" (EER 7(3)). Environmental Education Research, 9(2), 181-214. https://doi.org/10.1080/13504620303474.

Meyers, L. S., Gamst, G., \& Guarino, A. J. (2006). Applied multivariate research: Design and interpretation. Thousand Oaks, CA: Sage Publications.

Ministerio de Ambiente y Desarrollon Sostenible. (2016). Los proyectos ambientales escolares-PRAE en Colombia [School environmental projects-PRAE in Colombia]. Bogotá, Colombia: Ministerio de Ambiente y Desarrollon Sostenible.

Ministerio de Medio Ambiente y Ministerio de Educación Nacional. (2002). Politica Nacional de Educacion Ambiental: SINA [National Policy on Environmental Education: SINA]. Bogotá, Colombia: Ministerio de Educación Nacional.

Mortimore, P. (2009). Alternative models for analysing and representing countries' performance in PISA. Brussels, Belgium: Education International Research Institute.

Negev, M., Sagy, G., Garb, Y., Salzberg, A., \& Tal, A. (2008). Evaluating the environmental literacy of Israeli elementary and high school students. The Journal of Environmental Education, 39(2), 3-20. https://doi. org/10.3200/JOEE.39.2.3-20.

Organisation for Economic Co-operation and Development (OECD). (2007). Pisa 2006: Science competencies for tomorrow's world. Volume 1-Analysis. Paris, France: Author. https://doi.org/10.1787 /9789264040014-en.

Organisation for Economic Co-operation and Development (OECD). (2009). PISA 2006: Technical report. Paris, France: Author.

Organisation for Economic Co-operation and Development (OECD). (2013). The role of families in shaping students' engagement, drive and self-belief. In Ready to learn: Students' engagement, drive and selfbeliefs (Vol. III, pp. 141-162). Paris, France: Author.

Rakotomamonjy, S. N., Jones, J. P. G., Razafimanahaka, J. H., Ramamonjisoa, B., \& Williams, S. J. (2015). The effects of environmental education on children's and parents' knowledge and attitudes towards lemurs in rural Madagascar. Animal Conservation, 18(2), 157-166. https://doi.org/10.1111/acv.12153.

Rangel, C., \& Lleras, C. (2010). Educational inequality in Colombia: Family background, school quality and student achievement in Cartagena. International Studies in Sociology of Education, 20(4), 291-317. https://doi.org/10.1080/09620214.2010.530855.

Rockström, J., Steffen, W., Noone, K., Rockstrom, J., Steffen, W., Noone, K., . . Foley, J. A. (2009). A safe operating space for humanity. Nature, 461(September), 472-475.

Sauvé, L., Brunelle, R., \& Berryman, T. (2005). Influence of the globalized and globalizing sustainable development framework on national policies related to environmental education. Policy Futures in Education, 3(3), 271-283.

Savage, R. D., Britton, P. G., Bolton, N., \& Hall, E. H. (1973). Intellectual functioning in the aged. London, England: Methuen.

Steffen, W., Richardson, K., Rockstrom, J., Cornell, S. E., Fetzer, I., Bennett, E. M., Sorlin, S. (2015). Planetary boundaries: Guiding human development on a changing planet. Science, 347(6223), 1259855. https://doi.org/10.1126/science.1259855.

The World Bank. (2008). Colombia: The quality of education in Colombia: An analysis and options for a policy agenda. Washington, DC. Retrieved from https://openknowledge.worldbank.org/handle/10986 17875 .

The World Bank. (2016). World Bank Country and Lending Groups: Country Classification. Retrieved from https://datahelpdesk.worldbank.org/knowledgebase/articles/906519. Accessed 22 Aug 2016.

United Nations Development Programme (UNDP). (1998). Human development report 1998. New York, NY: Oxford University Press.

United Nations Educational, Scientific and Cultural Organization (UNESCO). (1978). Intergovernmental conference on environmental education: Final report (Tbilisi, Georgia, USSR). Paris, France: Author.

Wan, Y., \& Bi, H. (2019). What major "socio-scientific topics" should the science curriculum focused on? A Delphi study of the expert community in China. International Journal of Science and Mathematics Education. https://doi.org/10.1007/s10763-018-09947-y 